\title{
ASSESSING IN-SITU SEMI-NATURAL BUTTERFLY BREEDING APPROACH OF ORNITHOPTERA CROESUS (PAPILIONIDAE) ON BACAN ISLAND, MALUKU UTARA, INDONESIA
}

\author{
Djunijanti Peggie $^{* 1}$, Duncan Neville ${ }^{2}$, Sarino $^{1}$, and Sih Kahono ${ }^{1}$ \\ ${ }^{1}$ Museum Zoologicum Bogoriense, Research Center for Biology, \\ Indonesian Institute of Sciences (LIPI), \\ Jl. Raya Jakarta-Bogor Km. 46, Cibinong, Bogor 16911, Indonesia \\ ${ }^{2}$ formerly WWF program manager at Arfak, Papua, Indonesia \\ *Corresponding author:kupu2indonesia@gmail.com; djun002@lipi.go.id
}

Received: 8 June 2021; Accepted: 26 June 2021

\begin{abstract}
Indonesia is rich in endemic species of flora and fauna. One of them is Ornithoptera croesus butterfly, which is endemic to North Maluku. Habitat degradation and trade of this species have caused the populations to decline. To avoid the collection of butterfly specimens from nature and to preserve their habitat and population in nature, a semi-natural butterfly breeding practice at Bacan Island was initiated in 2013. This research was conducted to assess the breeding approach for $O$. croesus croesus using a qualitative descriptive method. The assessment was based on these variables: the specific ecology of the butterfly; the suitability of the breeding site and development model; the utilization of larval host plants and butterfly nectar plants; and the establishment of the birdwing population at the site. The observations and results are presented here. Based on the assessment, the in-situ semi-natural breeding approach is one of the solutions for sustainable use of this protected species.
\end{abstract}

Keywords: birdwing butterfly, breeding, conservation, Ornithoptera croesus, sustainable use

\begin{abstract}
ABSTRAK
Indonesia kaya akan spesies endemik flora dan fauna. Salah satunya adalah Ornithoptera croesus, spesies kupu-kupu endemik Maluku Utara. Degradasi habitat dan perdagangan spesies ini menyebabkan populasinya menurun. Untuk menghindari pengambilan spesimen kupu-kupu dari alam dan untuk menjaga kelestarian habitat dan populasinya di alam, telah dimulai penangkaran semi-alami di Pulau Bacan pada tahun 2013. Penelitian ini dilakukan untuk menilai pendekatan pengembangan semi alami untuk $O$. croesus croesus dengan menggunakan metoda deskriptif kualitatif. Penilaian dilakukan berdasarkan variabel berikut: kondisi ekologi bagi kupu-kupu ini; kesesuaian tempat penangkaran dan model pengembangan; penggunaan tanaman pakan larva dan pakan sumber nektar bagi kupu-kupu; dan keadaan populasi kupu-kupu sayap burung di lokasi penangkaran. Observasi dan hasil dipaparkan di sini. Berdasarkan penilaian, pendekatan penangkaran semi-alami merupakan sebuah solusi bagi pemanfaatan berkelanjutan kupu-kupu dilindungi ini.
\end{abstract}

Kata kunci: kupu-kupu sayap burung, penangkaran, konservasi, Ornithoptera croesus, pemanfaatan berkelanjutan

\section{INTRODUCTION}

As many as 2000 butterfly species are estimated to occur in Indonesia (Peggie, 2014). Some are endemic to certain islands or island groups, and others are commonly distributed throughout the archipelago. Some species of Indonesian papilionids have been flagged as 
threatened (Collins \& Morris, 1985; Endo \& Ueda, 2004) and conservation action plan has been suggested (New \& Collins, 1991). The understanding of the butterfly ecology, distribution, and threats should be the foundation of conservation programs (Sands \& New, 2013) and we are still in the effort of achieving basic data for Indonesian butterfly species.

On the island of Bacan, North Maluku, there are some endemic species (Peggie et al., 2005) including the beautifully brilliant-colored and highly demanded Wallace's Golden Birdwing, Ornithoptera croesus Wallace, 1859. This species has different subspecies on Bacan, Halmahera, and Morotai. Some even recognized distinct subspecies from the island of Kasiruta and Mandioli. The subspecies in Bacan is Ornithoptera croesus croesus Wallace, 1859 which is the focus of this paper. A further research, such as using mitochondrial and nuclear genes, may reveal speciation and diversification rates (Condamine et al., 2015) which may affect the conservation strategies. The strategies would be different if they in fact constitute same or different subspecies, in term of breeding and avoiding extirpation.

A study of the diversity of papilionid butterflies at Gunung Sibela Nature Reserve, Bacan (Mas'ud et al., 2016) showed that $O$. croesus croesus was found in very few numbers, only 12 individuals seen each sighting time, at four sites of altitude $20 \mathrm{~m}, 200 \mathrm{~m}, 400 \mathrm{~m}$, and $800 \mathrm{~m}$ asl. Tropical forests have experienced human disturbance from mild to severe conditions (Laurance et al., 2001). The most common disturbances are logging and land clearing for agriculture, and hunting (Whitworth et al., 2018).

Butterflies require at least two kinds of plants: leaves as food for the larvae and flower nectars as food for the adults. Butterflies and their larvae have specific associations that vary among species and groups (Feeny et al., 1983; Jermy, 1984; Bernays, 1992; Ferrer-Paris et al., 2013). Similarly, the abundance of these food sources determines the abundance of the butterfly population (Curtis et al., 2015). Therefore, the diversity and population of butterflies are highly dependent on the diversity and population of the host plants.

Though all birdwing butterflies are included in the Appendix II of CITES and are protected under Indonesian regulation (BKSDA, 1999; Peggie, 2011; KLHK, 2018), the high economic value of birdwing butterflies has attracted some people to obtain butterfly individuals in high numbers. In certain cases of endemic and rare species of Indonesian butterflies, declining populations due to habitat changes can be worsened by domestic and international trading (Soehartono \& Mardiastuti, 2002). In recent years, O. croesus butterfly is included as one of the candidates of Review of Significant Trade by CITES due to high volume of trades and the source code usage (CITES, 2020). 
Considering the IUCN status of $O$. croesus which has been classified as NT - near threatened (Böhm, 2018), direct collections of adults and pupae from the natural habitats should be avoided. For species with declining populations, conservation strategies need to be assessed (Schultz et al., 2008). A breeding facility exists on Bacan Island, in which an environmentally friendly method of semi-natural breeding of $O$. croesus croesus and a few other butterfly species was developed. The facility has created an environment to attract wild butterflies from nature to come to lay eggs, the larvae grow and develop to pupae, adults emerge out of the pupae, and population can establish well there. Captive breeding facilities can also provide the much-needed data on life history and other aspects of the species (Matsuka, 2001; Daniels et al., 2020). However, there has been no report on the breeding of O. croesus croesus in the facility. Therefore, this study aims to assess the breeding approach whether in-situ semi-natural breeding method meet the criteria for sustainable use of $O$. croesus croesus.

This research is part of our contribution to support the institutional role of LIPI as Indonesian Scientific Authority of CITES and also to provide insights to the Ministry of Environment and Forestry as Indonesian Management Authority of CITES.

\section{MATERIALS AND METHODS}

This research was conducted in April 2018 and September 2019 on Bacan Island, North Maluku using a qualitative descriptive method. We had background knowledge about the butterfly breeding facility prior to the surveys. Specific ecological aspects of $O$. croesus croesus were observed both in natural habitat at two different sites at Gunung Sibela (Fig. 1) and at the butterfly breeding facility. Basic ecological data is necessary to be obtained for better understanding of the butterfly conservation.

The study to assess the butterfly breeding approach was primarily carried out at an in-situ semi-natural butterfly breeding facility at Labuha, Bacan Island (Fig. 2a). In-situ means that the facility is located within the range of the subspecies. Semi-natural refers to the condition that larval host plants, nectar-providing plants, and other supporting plants were planted to enrich the area as to attract butterflies.

The variables to assess the breeding approach include: the specific ecological requirement of the $O$. croesus croesus that supports its breeding; the suitability of the breeding site and development model; the utilization of larval host plants and butterfly nectar plants; and the establishment of the birdwing population at the site. Additionally, the diversity of other butterflies that came to the area was also observed. 
Existing conditions of the facility were observed and recorded, including: the size of the facility, the size of the cage area or the butterfly enclosure, the condition of the surrounding, the butterfly species occurred inside the enclosure, the species and the number of larval host plants, the species and the number of nectar-providing plants. The occurrence of $O$. croesus croesus inside and outside the enclosure (Fig. 2b) was noted and recorded during the study from morning to afternoon for 3 days in 2018 and 2 days in 2019. Additional information was available from photographs taken several times in the past 5 years.

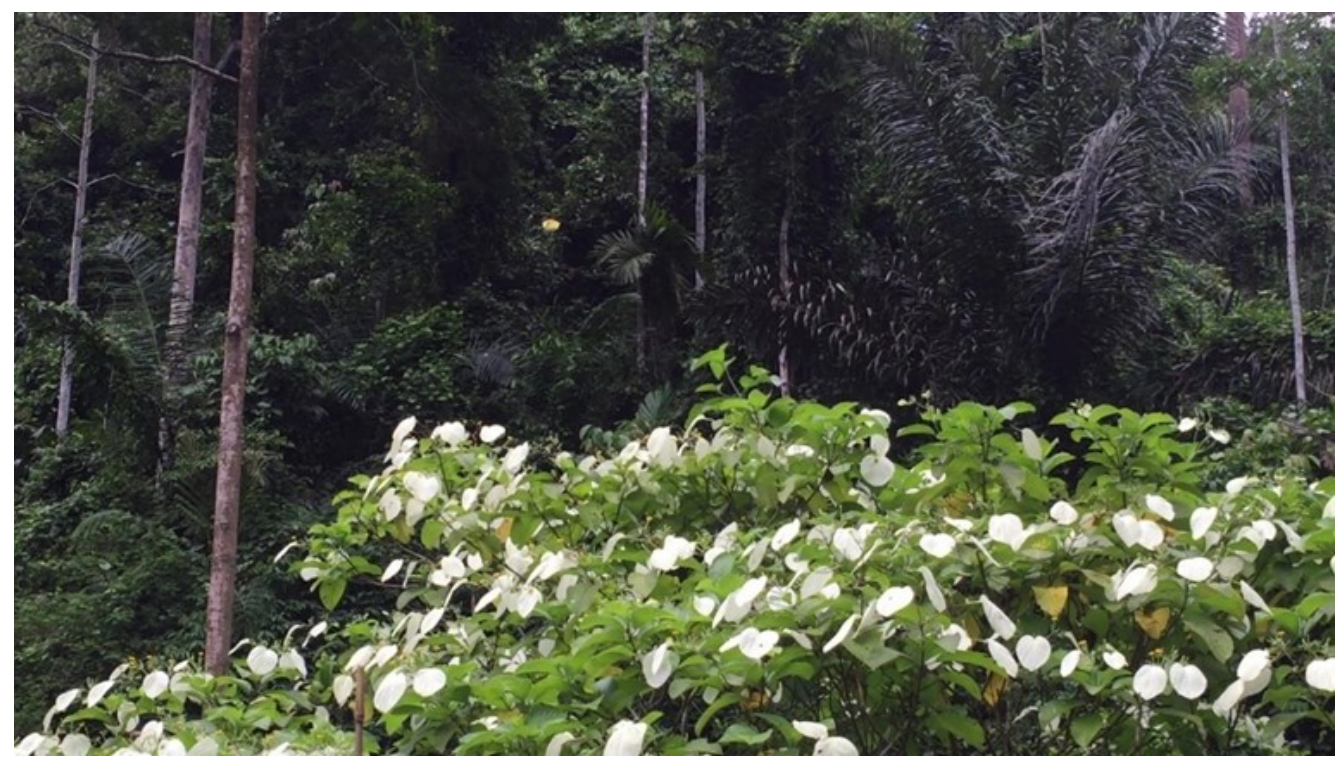

Figure 1. Habitat of $O$. croesus croesus at Gunung Sibela, Bacan.
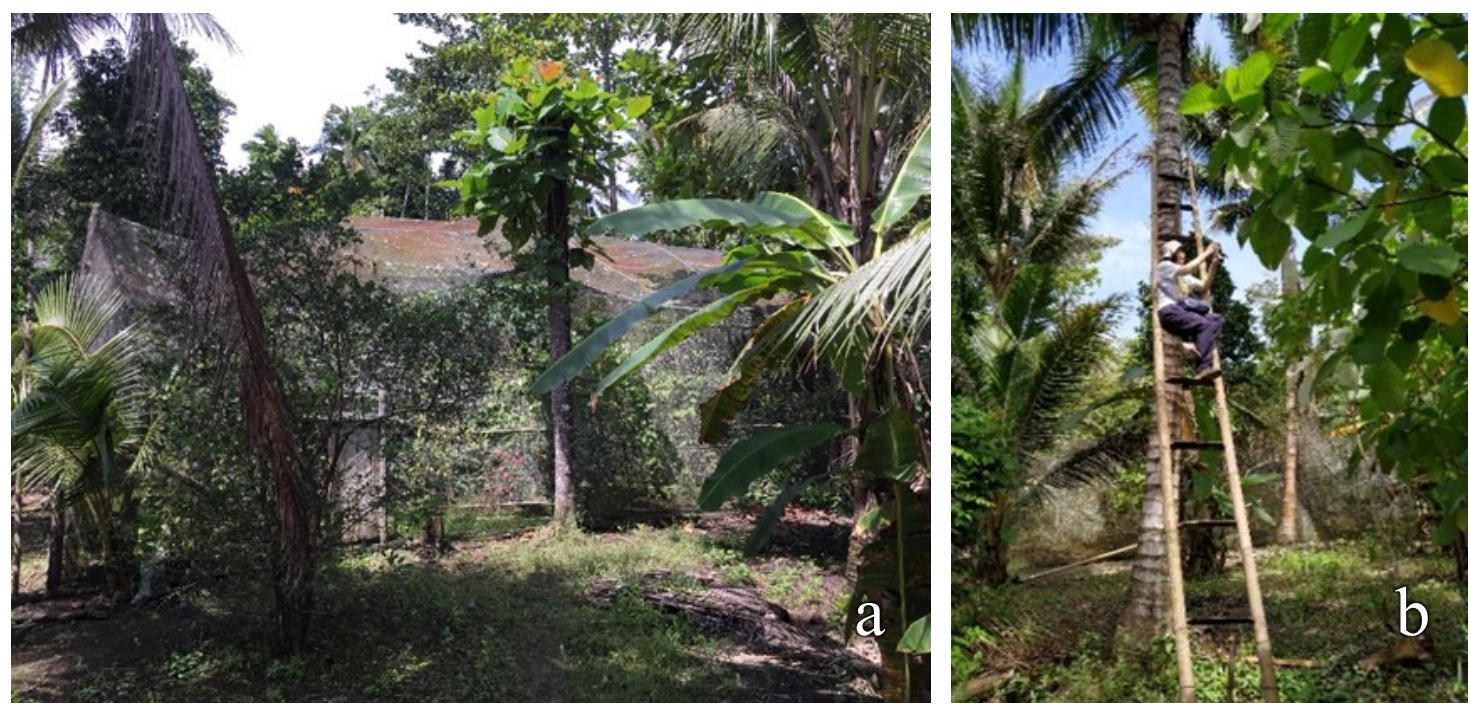

Figure 2. In-situ semi-natural butterfly breeding facility at Labuha, Bacan Island: a. butterfly cage or enclosure; b. area outside the enclosure with trees of Mussaenda sp. and a good spot to see incoming butterflies from the neighboring forest. 


\section{RESULTS}

\section{Specific ecological aspects of the butterfly in natural habitat and at the breeding facility}

The natural habitat of this butterfly is pristine forests of Gunung Sibela. We do not disclose the exact locality because of the rarity of the butterfly and it is a protected species. We walked up the river for about three hours in the first survey to reach a grand spot of flowering plants up the river, and two hours in the second survey to a different spot with similar condition.

There were two large trees of white petal-like calyx lobes Mussaenda sp. and some plants of red-flowered Hibiscus sp. at the first observation spot. The birdwing butterfly flew fast across a vast area of the forest five times (on April 14, 2018 between 10:30 and 13:15) and came to Mussaenda flowers twice (at 12:10 and 12:20) during a three-hour observation in the first survey. Like other swallowtails, they keep moving their wings while taking nectar on a flower (Fig. 3a). We observed that Hibiscus flowers were not visited by any butterfly. After the observation of the butterfly, we were shown the location of the native host plants, Pararistolochia sp., on the hill across the river from the Mussaenda trees.

At the second observation site, there were four large trees of Mussaenda sp. and no other flowering plants. During a three-hour observation in the second survey, on September 4, 2019, a male individual was observed taking nectar quickly on Mussaenda flowers at 9:39, was perching for a few seconds on a leaf of a high tree at 11:08, was seen taking nectar on Mussaenda at 12:28; and one female was seen taking nectar on Mussaenda at 12:40 (Fig. $3 b)$. We could not be certain whether the male is the same individual or different one.

The observation on September 5, 2019 at the breeding facility revealed that this butterfly was active at 8:30, seen on Mussaenda flowers, both inside the enclosure and outside. During their search for nectar, they could meet their partners to conduct mating (Fig. 3c). A female outside the enclosure was also observed seeking host plant leaves at 16:03. However, we could not see as to where she flew among the trees and vines, so we could not observe the ovipositing behavior. 

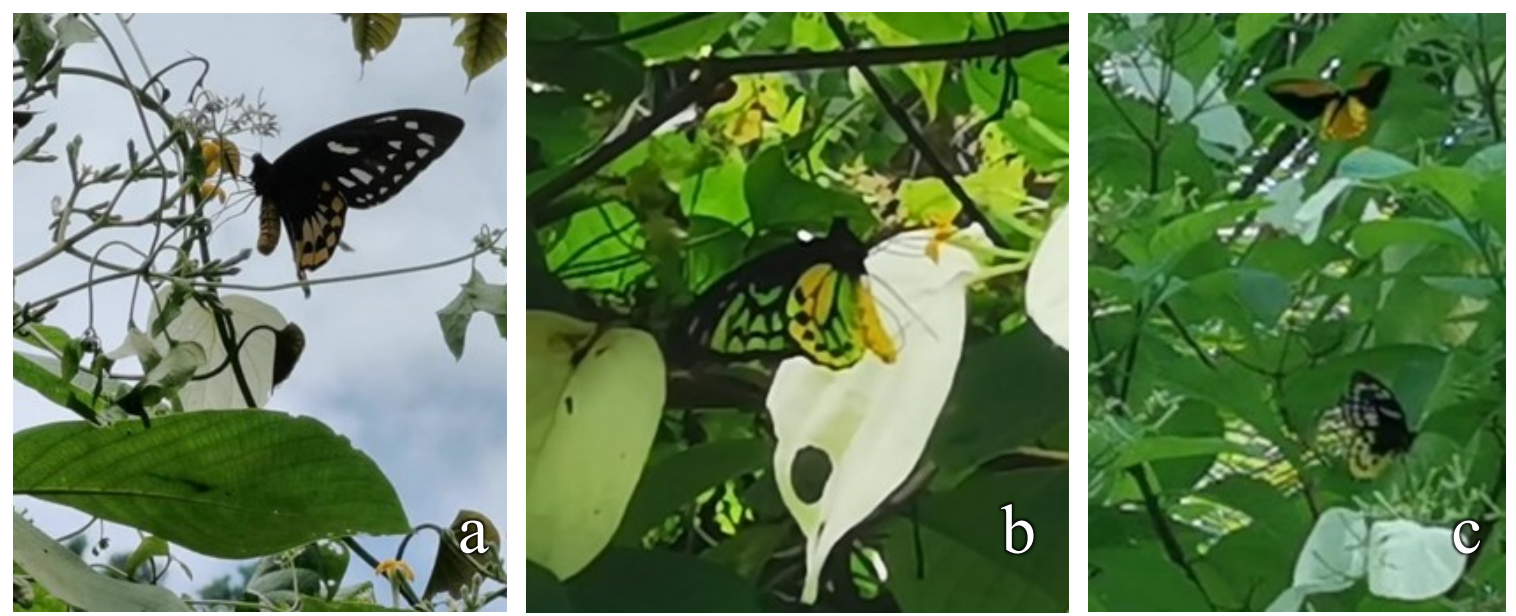

Figure 3. Observation of $O$. croesus: a. male on Mussaenda flowers at the natural habitat of Gunung Sibela, Bacan; b. female on Mussaenda flowers at Gunung Sibela; c. male (above) approached female (below) on Mussaenda flowers at the butterfly breeding facility at Labuha, Bacan.

\section{The site of in-situ semi-natural breeding facility}

The in-situ semi-natural breeding facility was started in 2013 on a piece of land, that was enriched with numerous larval host plants and nectar-providing plants. The overall size of the area is quite large, approximately three hectares. The land consists of mixed plantations, predominantly coconut trees, Mussaenda trees, palms, and over 50 plants of Aristolochia spp. climbing mainly on coconut trees. The trees of Mussaenda sp. reach on average 7 meters in height and 8 meters in canopy spread and have numerous flowers. At the further end of the land, which borders with a secondary forest, a butterfly enclosure was built. The size of the enclosure is about $500 \mathrm{~m}^{2}$ ( $28 \mathrm{~m}$ long $\mathrm{x} 18.5 \mathrm{~m}$ wide), and about $8 \mathrm{~m}$ high, covered by insect net. This large size is necessary to allow wider area for the birdwings to fly inside the enclosure. The top of the enclosure is not fully closed, some areas are left open, allowing butterflies from the wild to enter the enclosure to lay eggs on the host plants.

Prior to the initiation of the enclosure in 2013, the area was enriched with host plants and nectar plants to attract butterflies to the area. Female butterflies laid eggs on the host plants. Then parts of plants which had eggs or caterpillars were covered with large net sleeve (Fig. 4) to avoid any predators and parasites. Every day, the breeder would check if the caterpillars had enough leaves and would move the caterpillars to other branches if needed. This ranching practice is quite common among breeders to optimize the usage of host plants. After the pupae emerge into adults, they can be harvested and some are released to the wild for restocking. This practice meets the criteria for ranching of controlled environment. 

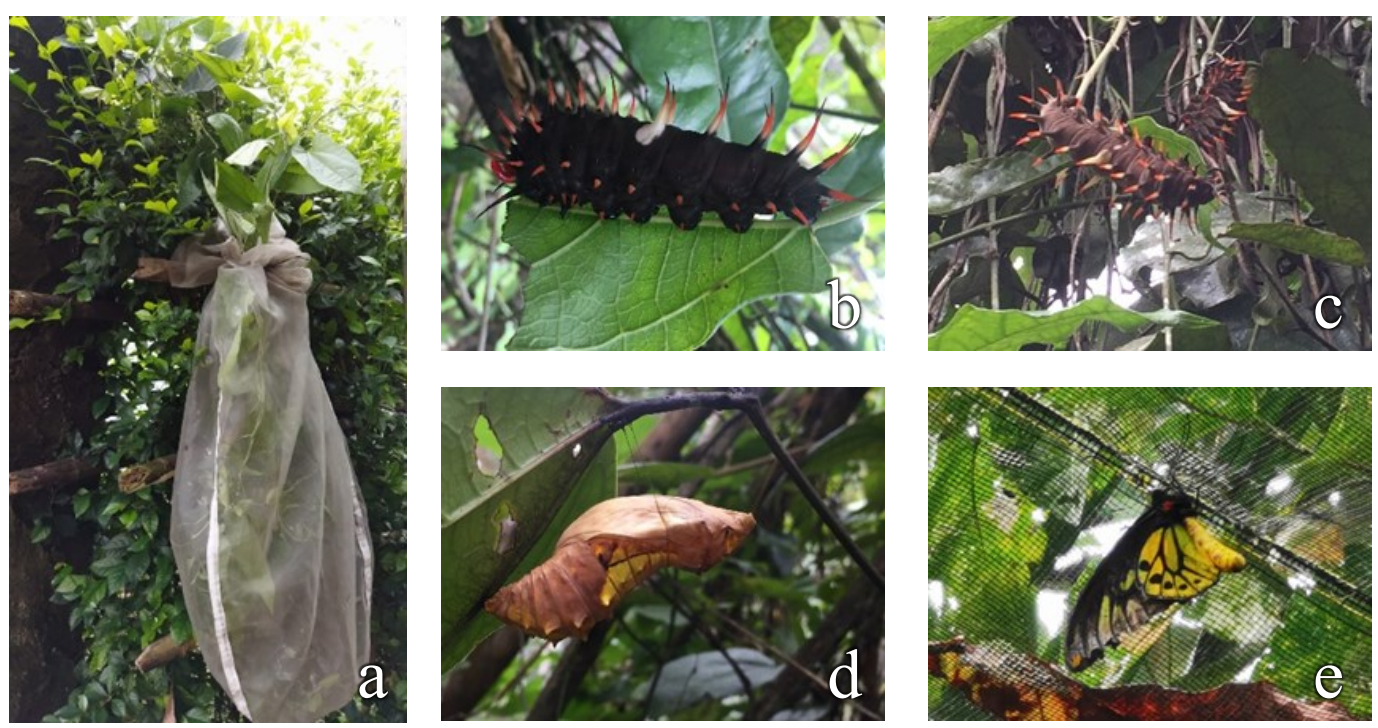

Figure 4. Approach to breeding butterflies: a. The ranching practice of keeping pre-adult stages on host plants covered with a large net sleeve; $\mathbf{b}$-e. the captive breeding practice of keeping pre-adult and adult stages inside a butterfly enclosure: b. $4^{\text {th }}$ instar larva on a leaf of $A$. acuminata, c. $5^{\text {th }}$ instar larvae on leaves of Pararistolochia sp., d. pupa, e. adult male of $O$. croesus croesus.

\section{Utilization of larval host plants and butterfly nectar plants}

Inside the enclosure, as many as 412 plants of Aristolochia acuminata (previously known as A. tagala, see Yao, 2015) from Bali, 375 plants of Aristolochia sp. from Obi, 346 plants of A. gaudichaudii from Papua, and 54 plants of Pararistolochia sp. (Fig. 5) were planted in 30 rows and 20 clusters. In addition to the host plants for O. croesus, in the enclosure there were also host plants for other butterfly species such as Papilio ulysses, $P$. lorquinianus, $P$. polytes, $P$. deiphobus, $P$. tydeus, and Graphium spp. Outside the enclosure, more than 50 plants of Aristolochia sp. were planted to support incoming butterflies.

The leaves of Aristolochia spp. were eaten by larvae of $O$. croesus croesus inside the enclosure. Additionally, the leaves of $A$. acuminata were also eaten by larvae of Troides criton, and Pachliopta polyphontes. We observed that $A$. acuminata was utilized as the primary host plants in the breeding site (Fig. 5a), but Pararistolochia sp. was found as the native host plants in the wild (Fig. 5b). At the breeding facility, O. croesus croesus prefers A. acuminata and thrives well on it. Nevertheless, we saw two larval individuals on Pararistolochia sp. (Fig. 4c).

Some flowering plants such as Clerodendrum sp., Ixora sp., and 84 plants of Mussaenda sp. (Fig. 6) are available inside the enclosure. We observed that only flowers of Mussaenda sp. were visited by $O$. croesus croesus. Other nectar plants were used by other smaller butterfly species. 

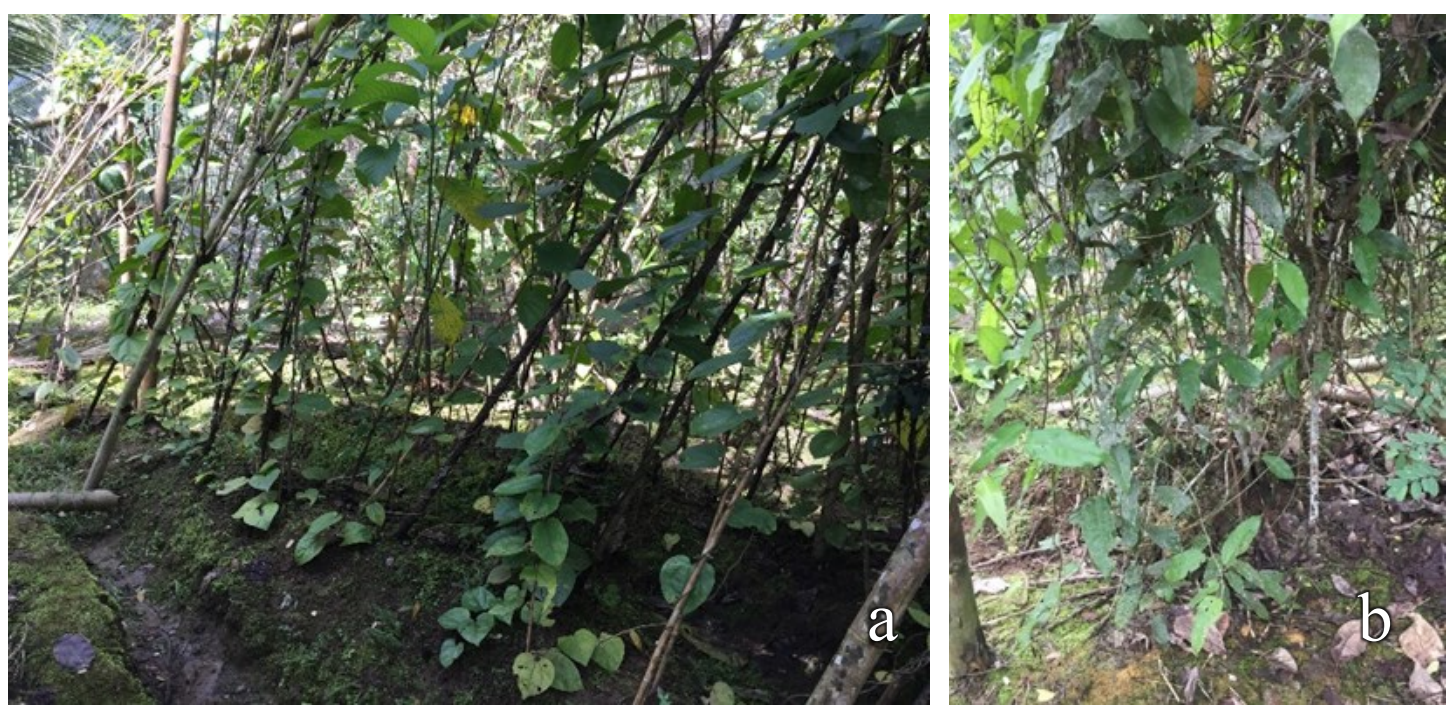

Figure 5. The larval host plants inside the butterfly breeding facility at Labuha, Bacan: a. rows of Aristolochia acuminata; b. rows of the native host plants, Pararistolochia sp.
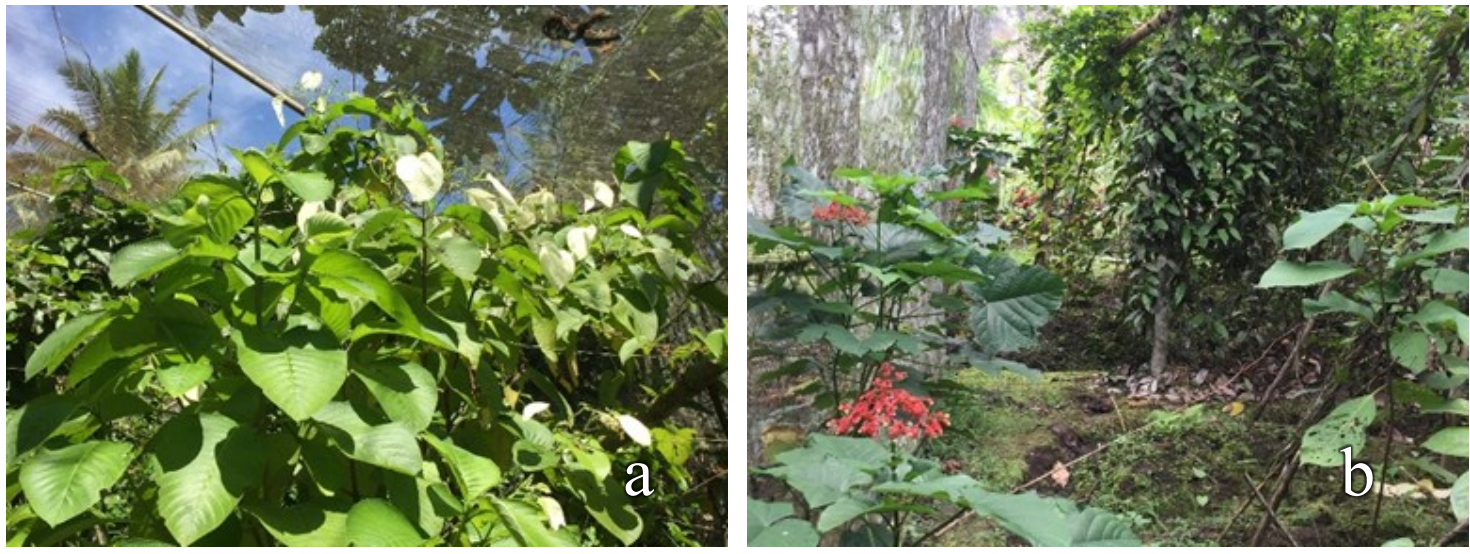

Figure 6. The flowering plants inside the butterfly breeding facility at Labuha, Bacan: a. Mussaenda sp.; b. Clerodendrum $\mathrm{sp.}$

\section{Birdwing population at the breeding site}

In our first survey in 2018, inside the enclosure we found more than 50 individuals of $4^{\text {th }}$ and $5^{\text {th }}$ instar larvae and more than 30 individuals of pupae of the butterfly. The numbers only included those we could see up to 2 meters. There would be many more on leaves above 2 meters as the vines of Aristolochia spp. reached the roof of the enclosure. There were no eggs and early stage larvae during our surveys. In our second survey in 2019 , we found similar numbers, with 3 adults seen inside the enclosure. These surveys confirmed the condition reported to us through photographs taken several times in the past 5 years prior to the surveys. Therefore, we could determine that $O$. croesus croesus has established the population at the site because of the numerous host plants and nectar plants, and also because of the supporting condition from the neighboring forest. 
At the breeding site, outside the enclosure, we observed adults of the species flew fast in and out of the area from the neighboring forest (Peggie et al., in prep.). At least nine other butterfly species were seen visiting flowers of Mussaenda trees, i.e. 6 species of Papilionidae: Pachliopta polyphontes, Papilio deiphobus, P. polytes, P. tydeus, P. ulysses and Troides criton; and 3 species of Nymphalidae: Danaus sp., Idea durvillei and Parthenos sylvia. Danaus was only identified to generic level as the butterfly was not collected and was only seen from afar.

\section{DISCUSSION}

Our encounters with $O$. croesus croesus at its natural habitat at Gunung Sibela Nature Reserve in both surveys confirmed the finding of Mas'ud et al. (2016) that O. croesus could only be found in very few numbers. We saw two to four individuals each time. Another issue to consider here is the question of whether the individuals seen flying across or towards the Mussaenda trees were the same individuals. In the case of Troides aeacus, radio telemetry was used to track the dispersal flight patterns (Wang et al., 2019). The distribution of this birdwing butterfly on Bacan Island is limited only to Gunung Sibela and perhaps two other farther locations (Alisi, pers. comm.). Thus, the rarity of this species should raise an alarm and become a major concern to all stakeholders.

Land clearings and cutting down trees at lower elevation of Gunung Sibela have probably affected the spatial distribution of this species as indicated by Mas'ud et al. (2016). In general, populations of numerous butterfly species have recently declined primarily due to habitat deterioration (Van Swaay et al., 2005; Van Dyck et al. 2009; Nakamura, 2011).

Our observation indicates that Mussaenda is the most preferred by $O$. croesus croesus and many other butterfly species. Mussaenda has large white petal-like calyx lobes (ClaßenBackhoff, 1996) that can be detected from long distances by butterflies, as shown in longranging Troides minos at a lowland forest in Western Ghats, India (Borges et al., 2003). We confirmed that the large white petal-like lobes can be very attractive for butterflies (Naiki \& Kato, 1999; Naiki, 2008) including O. croesus croesus to come for nectar.

The native host plants, Pararistolochia sp. were found across the river from the Mussaenda trees of the first observation site at Gunung Sibela. The presence of Pararistolochia sp. and Mussaenda sp. at Gunung Sibela confirmed that the specific ecological requirements for this species have been met. It has been reported by Igarashi \& Fukuda $(1997,2000)$ that O. croesus utilized Aristolochia gaudichaudii and two species of Pararistolochia. Although Pararistolochia spp. was thought to be the primary host plants 
(Igarashi \& Fukuda, 2000), when presented with some choices at the breeding facility, $O$. croesus croesus prefers $A$. acuminata, though two larval individuals were seen also on Pararistolochia sp. The requirement for plants in the breeding facility has been fulfilled by the presence of hundreds of plant individuals planted to enrich the area to attract butterflies.

Field observation revealed that this butterfly is a strong long-range flyer, thus requires extensive area to maneuver. The natural habitat fulfills this requirement very well, with vast area in the pristine forest. The requirement for extensive space can be fulfilled in the butterfly breeding facility as well. The size of the enclosure is quite large and high enough to allow space for flying inside the enclosure. The area outside the enclosure also provides ample space for the birdwing to fly, especially with the existence of neighboring forest. Therefore, specific ecological aspects, its requirements for plants and for movement area can be fulfilled both in the natural habitat and at the breeding facility.

Butterflies move from place to place to get enough food for themselves (D'Abrera, 1990), usually over long distances, so butterflies spend much energy to find nectar plants and host plants. Development of in-situ butterfly breeding model can be beneficial where the butterflies can find larval host plants and nectar-providing plants at the same place.

Some birdwing butterflies are known to be unpalatable to birds due to their noxious compounds derived from the host plants (Parsons, 1999). It is yet to be found out if $O$. croesus croesus is vulnerable to bird attack. Butterflies are prone to natural enemies, including parasitoids (Vinson, 1998; Santhosh \& Basavarajappa, 2019). The usage of butterfly enclosure as controlled environment can reduce the risk of death by natural enemies. However, even within the enclosed environment, some natural enemies were reported (Nacua et el., 2020) and need to be handled by butterfly breeders. While the openings at the top of the enclosure allowed incoming butterflies to enter, they also allowed the butterflies inside to escape and increase the risk of natural enemies.

To be categorized as a captive breeding facility, the openings at the top of the enclosure will need to be closed tightly. The totally closed enclosure involves more work of collecting eggs and early stage larvae from the plants outside of the enclosure and putting them into the enclosure to be protected from natural enemies.

Another model to facilitate sustainable trade of the birdwings would be a butterfly ranching operation, but this requires the facility to be in-situ at the natural habitat. The butterfly ranching operation such as that implemented by WWF at many scattered locations at the Arfak Mountain, Papua in 1990s emphasized on habitat enrichment (Neville, 1993). 
Adults emerged from pupae were harvested for trade with consideration that some were allowed to fly to replenish the area so populations are not diminished by the practice (Neville, 1993).

The suitability of the butterfly breeding site and the development model will influence the success of a breeding program. The elevation of the breeding site is very low, much lower than the natural habitat of $O$. croesus at about 300-400 m. Despite the low elevation of the butterfly breeding facility, we observed that it can support some butterfly species, even O. croesus. Apparently, the adjacent forest provides the nature stocks of the butterflies. In addition, adequate sunlight, ideal humidity and temperature need to be considered also in the controlled environment. On the second visit to the facility, we found similar condition of thriving population of $O$. croesus as in the first visit. Thus, the second variable of the assessment, i.e. the suitability of site and development model, is fulfilled, though a higher elevation would be better.

Increasing the availability of food sources in a controlled environment will reduce interand intra-species competition (Borror et al., 1996). With plentiful leaves of host plants and flowering plants available inside and outside the enclosure, the butterflies can be supported for the needs. Based on our observation, the third variable of the assessment, i.e. suitability of larval host plants and nectar-providing plants, is also fulfilled.

The fourth variable of the assessment is to determine whether the birdwing has established its population at the site. The number of pre-adults inside the enclosure and adults outside the enclosure showed that the birdwing has established its population at the breeding facility. The presence of some other butterfly species at the facility in both surveys indicated the diversity of butterflies. This was confirmed by the presence of larvae and pupae of Troides criton, Pachliopta polyphontes and Papilio spp. in the enclosure. Some other butterfly species were also sighted outside the enclosure.

We would like to reiterate that in-situ semi-natural butterfly breeding approach can be developed and recommended for butterfly conservation and sustainable use of $O$. croesus croesus on Bacan Island. Planting Mussaenda trees side by side with Aristolochia sp. is preferred so that the can get resources for both pre-adult and adult stages at the same place. The suitability of a site is an important factor to consider, in this case the adjacent forest provides suitable environment even for $O$. croesus to flourish. As observed at the natural habitat, $O$. croesus flies fast, high, and far, so the height of the enclosure is crucial for the success of the breeding operation. Therefore, having assessed the variables, we have come to the conclusion that in-situ semi-natural breeding approach for $O$. croesus is a viable option 
and meet the criteria for sustainable use of $O$. croesus croesus. This approach should be pursued with some improvements to be an effective model for sustainable use of the butterfly species.

Cooperation among all stakeholders is needed to conserve butterfly diversity and habitat preservation. Conservation measures can be taken through environmental friendly operations that satisfy stakeholders. Approach such as ranching and captive breeding practices need to be encouraged and supported. More importantly, the remaining forests on Bacan Island need to be preserved and the capacity to be increased to maintain the habitat and diversity of butterflies.

\section{ACKNOWLEDGMENTS}

The field surveys were carried out with DIPA funds from KSK CITES 3400.002.051A, Research Center for Biology - LIPI. We are grateful to KSK CITES and the director. We also thank the head of BKSDA Maluku and his staff for the access given to enter the areas on Bacan Island. We thank all those who have assisted us during the field surveys. We appreciate insights provided by reviewers to improve an earlier version of the manuscript.

\section{REFERENCES}

Bernays, E.A. 1992. Interaction of insects and plants. Sci. Progress Oxford, 76: 247-271.

BKSDA (Balai Konservasi Sumber Daya Alam). 1999. Peraturan Kementerian Lingkungan Hidup dan Kehutanan. http://ksdae.menlhk.go.id/assets/uploads/ Lampiran-PP-Nomor-7-Tahun-1999.

Böhm, M. 2018. Ornithoptera croesus. The IUCN Red List of Threatened Species 2018: e.T15517A727365. https://dx.doi.org/10.2305/IUCN.UK.2018-1.RLTS.T15517A727365.en. Downloaded on 4 June 2021. https://www.iucnredlist.org/species/15517/727365

Borges, R.M., Gowda, V. \& Zacharias, M. 2003. Butterfly pollination and high-contrast visual signals in a low-density distylous plant. Oecologia, 136: 571-573.

Borror D, Triplehorn, C.H. \& Johnson, N.F. 1996. An Introduction to the Study of Insects. Ohio [US]: Saunders College Publishing.

CITES. 2020. CITES Trade Data Base. Available at: http://trade.cites.org/. UNEP-WCMC. Accessed 2 June 2021.

Claßen-Backhoff, R. 1996. A survey of flower-like inflorescences in the Rubiaceae. E. Robbrecht, C. Puff \& E. Smets, eds. Second International Rubiaceae Conference Proceedings, Opera Botanica Belgica, 7: 329-367.

Collins, N.M. \& Morris, M.G. 1985. Threatened Swallowtail Butterflies of the World - The IUCN Red Data Book. Switzerland: Gland: International Union for Conservation of Nature and Natural Resources: $401 \mathrm{pp}+$ pls.

Condamine, F., Toussaint, E., Clamens, A-L., Genson, G., Sperling, F. \& Kergoat, G. 2015. Deciphering the evolution of birdwing butterflies 150 years after Alfred Russel Wallace. Scientific Reports, 5. 11860. 10.1038/srep11860.

Curtis R.J., Brereton, T.M., Dennis, R.L.H., Carbone, C. \& Isaac, N.J.B. 2015. Butterfly abundance is determined by food availability and is mediated by species traits. Journal of Applied Ecology, 52 (6): 1676-1684. 10.1111/1365-2664.12523 
D'Abrera.1990. Butterflies of the Australian Region. Third (revised) edition. Melbourne: Hill House: $416 \mathrm{pp}$.

Daniels, J.C., Hill, G.M., Rossetti, K.A., Sanchez, S.J. \& Hornfeldt, J.A. 2020. At-risk butterfly captive propagation programs to enhance life history knowledge and effective ex situ conservation techniques. J. Vis. Exp., (156), e60591, doi:10.3791/60591

Endo, T. \& Ueda, K. 2004. A Complete Guide to the Endangered Swallowtail Butterflies of the World. Japan: Tokyo: Endless Science Information: 100 pp.

Feeny, P., Rosenberry, L. \& Carter, M. 1983. Chemical aspects of oviposition behavior in butterflies. In: S. Ahmad, ed. Herbivorous Insects: Host-Seeking Behavior and Mechanisms, Academic Press: pp. 27-76. 10.1016/B978-0-12-045580-5.50007-0.

Ferrer-Paris J.R., Sanchez-Mercado, A., Viloria, A.L. \& Donaldson, J. 2013. Congruence and diversity of butterfly-host plant associations at higher taxonomic levels. PLOS ONE, 8(5): 1-15.

Igarashi, S. \& Fukuda, H. 1997. The Life Histories of Asian Butterflies. Vol. 1. Japan: Tokyo: Tokai University Press: pl. 304.

Igarashi, S. \& Fukuda, H. 2000. The Life Histories of Asian Butterflies. Vol. 2. Japan: Tokyo: Tokai University Press: pp. 305-306, pl. 10.

Jermy, T. 1984. Evolution of insect/host plant relationships. The American Naturalist, 124(5): 609630. http://www.jstor.org/stable/2461372

KLHK. 2018. Peraturan Menteri Lingkungan Hidup dan Kehutanan Republik Indonesia, Nomor P.106/MENLHK/setjen/Kum.1/12/2018. tentang perubahan kedua atas Peraturan Menteri LHK Nomor P.20/MENLHK/setjen/Kum.1/6/2018 tentang jenis tumbuhan dan satwa yang dilindungi.

Laurance, W.F., Pérez-Salicrup, D., Delamônica, P., Fearnside, P.M., D'Angelo, S., Jerozolinski, A., Pohl, L. \& Lovejoy, T.E. 2001. Rain forest fragmentation and the structure of Amazonian liana communities. Ecology, 82(1): 105-116.

Mas'ud A., Hasan, S. \& Abdullah, A. 2016. Diversity of butterfly family Papilionidae (Papilio ulysses and Ornithoptera croesus) on altitudinal stages of conserved forest of Mount Sibela, Bacan Island. Proceeding of National Seminar on Biodiversity VI, Surabaya 3 September 2016, pp. 239-245 (translated).

Matsuka, H. 2001. Natural History of Birdwing Butterflies. Tokyo: Matsuka Shuppan.

Nacua, A.E., Clemente, K.J., Macalalad, E.P., Galvez, M.C., Belo, L.P., Orbecido, A.H., Custer C. Deocaris, C.C. 2020. Butterflies behaviors and their natural enemies and predators in Manila, Philippines. Asian Journal of Conservation Biology, 9(2): 240-245.

Naiki, A. 2008. Breeding system in Mussaenda shikokiana (Rubiaceae). Bulletin of the Osaka Museum of Natural History, (62): 21-26.

Naiki, A. \& Kato, M. 1999. Pollination system and evolution of dioecy from distyly in Mussaenda parviflora (Rubiaceae). Plant Species Biology, 14: 217-227.

Nakamura Y. 2011. Conservation of butterflies in Japan: status, actions and strategy. $J$ Insect Conserv., 15: 5-22.

Neville, D. 1993. Butterfly farming as a conservation tool, Lessons learnt during implementation of butterfly farming in the Arfak Mountains, Irian Jaya. Presented at the International Butterfly Conference, Ujung Pandang, pp. 24-27.

New, T.R. \& Collins, N.M. 1991. Swallowtail Butterflies: An Action Plan for Their Conservation. Switzerland: Gland: International Union for Conservation of Nature and Natural Resources/ Species Survival Commission Lepidoptera Specialist Group.

Parsons, M. 1999. The Butterflies of Papua New Guinea. Their Systematics and Biology. San Diego: Academic Press: 736 pp.

Peggie, D. 2011. Precious and Protected Indonesian Butterflies. Bogor: Nagao NEF \& Pusat Penelitian Biologi: 72 pp. 
Peggie, D. 2014. Mengenal Kupu-kupu. Jakarta: Pandu Aksara Publishing: 78 pp.

Peggie, D., A. Rawlins \& R.I. Vane-Wright. 2005. An illustrated checklist of the papilionid butterflies (Lepidoptera: Papilionidae) of northern and central Maluku, Indonesia. Nachrichten des entomologischen Vereins Apollo (NEVA), N.F. $26(1 / 2), 41-60$.

Sands, D.P.A. \& New, T.R. 2013. Conservation of the Richmond Birdwing Butterfly in Australia. Dordrecht: Springer. https://doi.org/10.1007/978-94-007-7170-3_1

Santhosh S. \& Basavarajappa, S. 2017. Record of natural enemies of few butterfly species amidst agriculture ecosystems of Chamarajanagar district, Karnataka, India. Research Journal of Life Sciences, Bioinformatics, Pharmaceutical and Chemical Sciences 2(5): 18-31. DOI $10.26479 / 2017.0205 .02$

Schultz, C., Russell, C. \& Wynn, L. 2008. Restoration, reintroduction, and captive propagation for at -risk butterflies: A review of British and American conservation efforts. Israel Journal of Ecology \& Evolution, 54: 41-61. 10.1560/IJEE.54.1.41.

Soehartono, T. \& Mardiastuti, A. 2002. CITES Implementation in Indonesia. Nagao Natural Environment Foundation: 373 pp.

Van Dyck H., Van Strien A.J., Maes, D. \& Van Swaay, C. 2009. Declines in common, widespread butterflies in a landscape under intense human use. Conserv. Biol., 23: 957-965.

Van Swaay C., Warren, M. \& Loi"s, G. 2005. Biotope use and trends of European butterflies. $J$ Insect Conserv., 10: 189-209.

Vinson, S.B. 1998. The general host selection behavior of parasitoid Hymenoptera and a comparison of initial strategies utilized by larvaphagous and oophagous species. Biological Control, 11(2): 79-96.

Wang, Z., Huang, Y. \& Pierce, N.E. 2019. Radio telemetry helps record the dispersal patterns of birdwing butterflies in mountainous habitats: Golden Birdwing (Troides aeacus) as an example. Journal of Insect Conservation. 23. 10.1007/s10841-019-00167-5.

Whitworth A., Huarcaya, R.P., Mercado, H.G., Braunholtz, L.D. \& MacLeod, R. 2018. Food for thought. Rainforest carrion-feeding butterflies are more sensitive indicators of disturbance history than fruit feeders. Biological Conservation, 217: 383-390.

Yao, T.L. 2015. Aristolochiaceae. In: R. Kiew, R.C.K. Chung, L.G. Saw \& E. Soepadmo, eds. Flora of Peninsular Malaysia. Selangor, Malaysia: Forest Research Institute Malaysia: pp. 5-46. 